\title{
Dry Matter Production and Harvest Index of Groundnut (Arachis hypogaea L.) Varieties Under Irrigation
}

\author{
A. A. Mukhtar ${ }^{1}$, B. A. Babaji ${ }^{1}$, S. Ibrahim², H. Mani ${ }^{3}$, A. A. Mohammad ${ }^{1} \&$ A. Ibrahim ${ }^{4}$ \\ ${ }^{1}$ Department of Agronomy, Faculty of Agriculture, Ahmadu Bello University Zaria, Zaria 1044, Nigeria \\ ${ }^{2}$ Department of Biochemistry, Faculty of Science, Ahmadu Bello University, Zaria, Nigeria \\ ${ }^{3}$ Institute for Agricultural Research, Ahmadu Bello University, Zaira, Nigeria \\ ${ }^{4}$ Faculty of Human Ecology, Universiti Putra Malaysia, Sri Serdang 43400, Malaysia \\ Correspondence: A. A. Mukhtar, Department of Agronomy, Faculty of Agriculture, Ahmadu Bello University \\ Zaria, Zaria 1044, Nigeria. E-mail: yayaaishang@yahoo.com
}

\author{
Received: December 1, 2012 Accepted: February 17, 2013 Online Published: July 15, 2013 \\ doi: $10.5539 /$ jas.v5n8p 153 \\ URL: http://dx.doi.org/10.5539/jas.v5n8p153
}

\begin{abstract}
Dry matter production for crops is generally influenced by the fertility status of the soil. Plant population may indirectly affect the amount of dry matter production due to its relationship with number of plants per unit area. An experiment to study the effect of plant population and basin size on dry matter production and other yield components of groundnut (Arachis hypogaea L.) varieties under irrigation was conducted during the dry seasons of 2004 to 2006 at the Irrigation Research Station of the Institute for Agricultural Research (IAR), Ahmadu Bello University at Kadawa. The treatments tested were three basin sizes ( $3 \mathrm{~m} \mathrm{x} \mathrm{3m,} \mathrm{3m} \mathrm{x} 4 \mathrm{~m}$ and $3 \mathrm{~m} \times 5 \mathrm{~m}$ ), three plant populations $\left(50,000,100,000\right.$ and 200,000 plants $\mathrm{ha}^{-1}$ and three varieties (SAMNUT 23, SAMNUT 21 and SAMNUT 11). These were arranged factorally in a split plot design with plant population and variety assigned to the main plots and basin sizes in the sub plots. SAMNUT 23 had higher harvest index than the other varieties, however SAMNUT 11 recorded the highest dry matter plant ${ }^{-1}$. Dry matter production was significantly highest at 100.000 plants ha $^{-1}$, while significantly highest harvest index was observed at 200,000 plants ha ${ }^{-1}$. SAMNUT 23 exhibited highest harvest index compared to the other varieties used in this study.
\end{abstract}

Keywords: groundnut varieties, irrigation, dry matter production, plant spacing

\section{Introduction}

Groundnut is an annual legume cultivated throughout the tropics and beyond; its cultivation is limited by the occurrence of frost (Anonymous, 2000). It is a short herbaceous annual belonging to the subfamily papilionaceae of the family Leguminosae. Essentially groundnut is a warm season crop requiring abundant sunshine for normal development. The crop development and maturity period are mainly dependent on the temperature (De Waele and Swanevelder, 2001). The mean daily temperature for optimum growth is 22 to $28^{\circ} \mathrm{C}$; a reduction in yield occurs above $33^{\circ} \mathrm{C}$ and below $18^{\circ} \mathrm{C}$ (Anonymous, 2002). It also requires enough soil moisture from the beginning of flowering up to two weeks before harvest. Dry matter production and accumulation in most arable crops is affected by photosynthesis and respiration. These factors which ultimately influence crop performance are affected by climate, soil fertility, moisture availability, pests and diseases, as well as socio-cultural practices. Amongst the cultural practices, plant spacing and density have significant effect on dry matter production.

Bell et al. (1987) observed that biological yield (above ground biomass plus pods) increased markedly $\left(12,600-16,900 \mathrm{~kg} \mathrm{ha}^{-1}\right)$ with increasing density up to the maximum of 588,000 plants ha ${ }^{-1}$. Especially in the Sudan savanna regions, groundnut haulms serve as excellent source of feed for livestock as well as organic matter source for soil improvement. The groundnut crop may be grown for both the seeds and for fodder. To this end dual purpose groundnut varieties have been bred at IAR Zaria providing farmers with both seed and fodder for human consumption and for livestock res [ectively. Similarly there are varieties bred for high seed yield although moderate amounts of fodder may be obtained: thus there is a need to explore ways to increase output of this important feed source for livestock.

Harvest index (HI), a measure of crop yield is the weight of harvested product as a percentage of the total plant weight of a crop. The concept has been used in crop improvement and physiology. Ahmad et al. (2007) observed 
that low crop harvest index is the major cause of less crop yield. They further opined that low crop HI could be attributed to cultivation of non recommended crop cultivars, unapproved seed for sowing, late sowing, imperfect sowing methods, low plant population, poor plant protection and proliferation of weeds, unbalanced use of fertilizer and non availability of water for irrigation at critical growth stages. However, studies by Bindi et al. (1999) show that change in harvest index is stable over a range of growth conditions which include irrigation and fertility treatments. In an experiment with four groundnut genotypes, Bell et al. (1992) found that change in harvest index over time varied from 0.0050 to $0.0140 \mathrm{HI} \mathrm{d}^{-1}$.

Conventionally, groundnut cultivation in Nigeria is carried out mostly by smallholder farmers during the wet season under rain fed conditions with limited inputs. However where rainfall is not adequate the crop can be grown under irrigation.

Groundnut production with irrigation is an uncommon practice in the Sudan savanna zone of Nigeria. Results of research conducted elsewhere in the world however have shown that pod and haulm yields of groundnut obtained under irrigation are higher than those obtained during the rainy season. Studies by Ishag (2000) on the growth of groundnut with irrigation have shown that the provision of adequate moisture during important phenological growth stages has a marked influence in terms of dry matter production, economic yield and yield components. This is due to the fact that there is better control over moisture supply during an irrigated than a rainfed season. Moreover mid season, end of season and other inconsistensis associated with with rainy season are avoided under irrigated conditions. This experiment was thus conducted to study the dry matter production and harvest index of groundnut varieties at varying plant populations under irrigation.

\section{Materials and Method}

\subsection{Experimental Site}

Field trials were conducted at the Irrigation Research Substation of the Institute for Agricultural

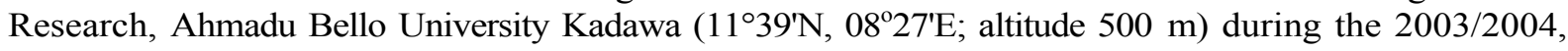
$2004 / 2005$ and 2005/2006 dry seasons. The substation is located in the Sudan Savanna ecological zone of Nigeria where the dry season starts in October to the end of May.

\subsection{Land Preparation}

After harrowing and ridging at $0.75 \mathrm{~m}$ width, the field was marked out into plots and thereafter leveled. The gross plots were $3 \mathrm{~m} \mathrm{x} 3 \mathrm{~m} ; 3 \mathrm{~m} \mathrm{x} 4 \mathrm{~m}$ and $3 \mathrm{~m} \times 5 \mathrm{~m}$ of about $20 \mathrm{~cm}$ depth. Sowing was done at a fixed inter-row plant spacing of $50 \mathrm{~cm}$. The intra-row plant spacing was however varied at 40,20 and $10 \mathrm{~cm}$ leading to plant density of 50000, 100000 and 200000 plants ha ${ }^{-1}$ respectively.

\subsection{Sowing}

In this process 2 seeds per hole were sown at a depth of about $3 \mathrm{~cm}$ by hand in all the years of the experiment.

The crop was fertilized with $20 \mathrm{~kg} \mathrm{~N}, 23.6 \mathrm{~kg} \mathrm{P}$ and $24.9 \mathrm{~K} / \mathrm{ha}^{-1}$ as basal dose using urea, single super phosphate (SSP) and muriate of potash (MOP)

\subsection{Weed Control}

This was done by pre-emergence application of Metolachlor + Terbutryne (Igram Combi $\left.{ }^{(\mathrm{R})} 500 \mathrm{EC}\right)$ at the rate of 4 liters ha ${ }^{-1}$ with a CP20 knapsack sprayer. Hoe weeding at four (4) and eight (8) weeks after sowing (WAS) was done in order to remove the weeds that emerged later.

\subsection{Harvesting}

The net plots were harvested by digging out the whole plant including the pods with a hoe and picking up the remaining pods from the soil.

\subsection{Data Collection}

Starting from 3WAS two plants were randomly selected from the border rows in each gross plot, at 3, 6, 9 12 WAS and at harvest, uprooted and oven dried to constant weight for 48 hours at $70^{\circ} \mathrm{C}$. The oven-dried samples were weighed using a Mettler balance model P1200 and the value recorded to obtain the total dry matter. Harvest index: the ratio of the seed yield to the total dry matter was calculated at harvest using the formula:

$$
K=\frac{\text { Grain yield from sample of TDM }}{\text { X g TDM sample }} \times 100
$$


Where $\mathrm{K}=$ harvest index, TDM $=$ Total dry matter $(\mathrm{g})$.

\subsection{Data Analysis}

Data collected were subjected to statistical analysis of variance using SAS (SAS Institute Inc.) statistical software. Where the $\mathrm{F}$ values were found to be significant, the treatment means were separated using Duncan Multiple Range Test DMRT (Duncan, 1955).

\section{Results}

At 3 WAS, the effect of plant population on total dry matter (TDM) was significant only in 2004/2005 and $2005 / 2006$ and when the result was combined (Table 1). TDM was significantly higher at 200,000 plants ha ${ }^{-1}$ in $2004 / 2005,2005 / 2006$ and the combined but was statistically at par with that at 100,000 plants ha ${ }^{-1}$. The least TDM was produced at 50,000 plants $\mathrm{ha}^{-1}$. The combined result showed that significantly highest TDM was achieved at 200,000 and 100,000 plants $\mathrm{ha}^{-1}$. The varieties exhibited significant differences in their TDM across the years. SAMNUT 11 produced significantly higher TDM than SAMNUT 21 in 2003/2004 but was statistically at par with TDM of SAMNUT 23. In 2004/2005, SAMNUT 21 had significantly higher TDM than SAMNUT 23 and 11. When the result was combined, TDM from, SAMNUT 21 was higher than SAMNUT 23, but was statistically at par with SAMNUT 11.

Table 1. Effect of plant population and basin size on total dry matter $(\mathrm{g})$ at 3 WAS of three groundnut varieties during 2003/2004, 2004/2005 and 2005/2006 dry season at Kadawa

\begin{tabular}{lllll}
\hline Treatments/Years & $2003 / 2004$ & $2004 / 2005$ & $2005 / 2006$ & Combined \\
\hline Plant Population ('000 ${\text { plants } \mathrm{ha}^{-1} \text { ) }}$ & & & & \\
50 & 0.98 & $1.56 \mathrm{~b}$ & $1.11 \mathrm{~b}$ & $1.22 \mathrm{~b}$ \\
100 & 1.05 & $1.75 \mathrm{ab}$ & $1.24 \mathrm{ab}$ & $1.35 \mathrm{a}$ \\
200 & 1.16 & $1.95 \mathrm{a}$ & $1.39 \mathrm{a}$ & $1.50 \mathrm{a}$ \\
SE \pm & 0.052 & 0.122 & 0.064 & 0.110 \\
Variety & & & & \\
SAMNUT 23 & $1.05 \mathrm{ab}$ & $1.61 \mathrm{~b}$ & 1.16 & $1.27 \mathrm{~b}$ \\
SAMNUT 21 & $0.92 \mathrm{~b}$ & $2.05 \mathrm{a}$ & 1.32 & $1.43 \mathrm{a}$ \\
SAMNUT 11 & $1.21 \mathrm{a}$ & $1.61 \mathrm{~b}$ & 1.25 & $1.36 \mathrm{ab}$ \\
SE \pm & 0.052 & 0.122 & 0.064 & 0.110 \\
Basin size & & & & \\
$3 \mathrm{~m} \times$ 3m & 1.07 & 1.69 & 1.22 & 1.33 \\
$3 \mathrm{~m} \times$ 4m & 1.05 & 1.89 & 1.31 & 1.42 \\
$3 \mathrm{~m} \times 5 \mathrm{~m}$ & 1.06 & 1.68 & 1.20 & 1.31 \\
SE \pm & 0.063 & 0.097 & 0.061 & 0.074 \\
Interaction & & & & \\
P x V & $\mathrm{NS}$ & $\mathrm{NS}$ & $\mathrm{NS}$ & $\mathrm{NS}$ \\
P x B & $\mathrm{NS}$ & $\mathrm{NS}$ & $\mathrm{NS}$ & $\mathrm{NS}$ \\
V x B & $\mathrm{NS}$ & $\mathrm{NS}$ & $\mathrm{NS}$ & $\mathrm{NS}$ \\
P x V x B & $\mathrm{NS}$ & $\mathrm{NS}$ & $\mathrm{NS}$ & $\mathrm{NS}$ \\
\hline
\end{tabular}

NS- Not significant. Means followed by the same letter within the same treatment group and year are statistically the same.

At 6 WAS there were no significant changes in TDM as a result of changes in plant population (Table 2). The varieties were not significantly different in their TDM in 2004/2005, 2005/2006 and combined. However in 2003/2004, SAMNUT 23 and SAMNUT 11 had significantly higher TDM than SAMNUT 21. 
Table 2. Effect of plant population and basin size on total dry matter $(\mathrm{g})$ at 6 WAS of three groundnut varieties during 2003/2004, 2004/2005 and 2005/2006 dry season at Kadawa

\begin{tabular}{lllll}
\hline Treatments/Years & $2003 / 2004$ & $2004 / 2005$ & $2005 / 2006$ & Combined \\
\hline Plant Population ('000 plants ha $^{-1}$ ) & & & & \\
50 & 1.71 & 6.47 & 2.99 & 3.72 \\
100 & 1.77 & 6.47 & 3.04 & 3.76 \\
200 & 1.65 & 6.89 & 3.19 & 3.91 \\
SE \pm & 0.080 & 0.483 & 0.246 & 0.427 \\
Variety & & & & \\
SAMNUT 23 & $1.98 \mathrm{a}$ & 6.34 & 2.94 & 3.77 \\
SAMNUT 21 & $1.26 \mathrm{~b}$ & 7.33 & 3.13 & 3.91 \\
SAMNUT 11 & $1.89 \mathrm{a}$ & 6.31 & 2.93 & 3.71 \\
SE \pm & 0.080 & 0.483 & 0.246 & 0.427 \\
Basin size & & & & \\
$3 \mathrm{~m} \times$ 3m & 1.67 & 6.42 & 2.92 & 3.70 \\
$3 \mathrm{~m} \times$ 4m & 1.80 & 6.76 & 3.12 & 3.89 \\
$3 \mathrm{~m} \times$ 5m & 1.66 & 6.71 & 3.02 & 3.80 \\
SE \pm & 0.081 & 0.431 & 0.222 & 0.257 \\
Interaction & & & & \\
P x V & $\mathrm{NS}$ & $\mathrm{NS}$ & $\mathrm{NS}$ & $\mathrm{NS}$ \\
P x B & $\mathrm{NS}$ & $\mathrm{NS}$ & $\mathrm{NS}$ & $\mathrm{NS}$ \\
V x B & $\mathrm{NS}$ & $\mathrm{NS}$ & $\mathrm{NS}$ & $\mathrm{NS}$ \\
P x V x B & $\mathrm{NS}$ & $\mathrm{NS}$ & $\mathrm{NS}$ & $\mathrm{NS}$ \\
\hline
\end{tabular}

NS- Not significant. Means followed by the same letter within the same treatment group and year are statistically the same.

At 9 WAS there were no significant differences in TDM due to plant population in 2003/2004 (Table 3). In $2004 / 2005$ and 2005/2006 however, TDM was significantly higher in the 200,000 plants ha $^{-1}$ than the 50,000 plants $\mathrm{ha}^{-1}$ but was statistically at par with the 100,000 plants $\mathrm{ha}^{-1}$. The combined result showed that a significantly higher TDM was attained at the 200,000 plants ha ${ }^{-1}$ and 100,000 plants ha ${ }^{-1}$ than at the 50,000 plants ha ${ }^{-1}$. There were significant differences among the varieties in their TDM in the three years. SAMNUT 23 and SAMNUT 11 produced significantly higher TDM than SAMNUT 21 in all the years and combined although SAMNUT 23 was at par with SAMNUT 21 in 2004/2005. There were significant interactions $(\mathrm{P} \leq 0.05)$ between plant population and variety in 2003/2004; and plant population and basin size in the combined. In 2003/2004 season the variety by population interaction showed that significantly highest total dry matter was produced by SAMNUT 11 at 50,000 plants $\mathrm{ha}^{-1}$. This was statistically similar to that produced by SAMNUT 23 at 100,000 plants $\mathrm{ha}^{-1}$ (Table 4). SAMNUT 21 produced its highest TDM at 200,000 plants ha ${ }^{-1}$. For $3 \mathrm{~m} \mathrm{x} \mathrm{3m} \mathrm{and} 3 \mathrm{~m} \mathrm{x} 4 \mathrm{~m}$ each increase in plant population resulted to an increase in TDM. The widest basin size having the highest plant population gave the highest TDM plant ${ }^{-1}$. Significantly highest total dry matter was obtained at 200,000 plants ha ${ }^{-1}$ in the $3 \mathrm{~m} \times 5 \mathrm{~m}$ basin, the least being observed in the $3 \mathrm{~m} \times 3 \mathrm{~m}$ basin at 50,000 plants ha ${ }^{-1}$ (Table 4 ). For the $3 \mathrm{~m} \times 5 \mathrm{~m}$ basin increase in plant population to 100,000 plants $^{-1} \mathrm{a}^{-1}$ led to significant reduction in TDM, however further increase in plant population to 200,000 plants ha $^{-1}$ in this basin led to significant increase in TDM.

TDM at 12WAS was unaffected by the different plant population (Table 5) in all the years and when the results were combined. Significant differences were observed between varieties in their TDM production in all the years and when combined. SAMNUT 11 produced the highest TDM at 12 WAS in all the years and when combined but was similar to SAMNUT 21 in 2005/2006. SAMNUT 21 had significantly higher TDM than SAMNUT 23 in 2005/2006 and the combined but was similar to SAMNUT 23 in 2003/2004 and 2004/2005. 
Table 3. Effect of plant population and basin size on total dry matter $(\mathrm{g})$ at 9 WAS of three groundnut varieties during 2004, 2005 and 2006 dry season at Kadawa

\begin{tabular}{lllll}
\hline Treatments/Years & 2004 & 2005 & 2006 & Combined \\
\hline Plant Population ('000plants ha $\left.{ }^{-1}\right)$ & & & & \\
50 & 3.60 & $25.52 \mathrm{~b}$ & $13.39 \mathrm{~b}$ & $14.17 \mathrm{~b}$ \\
100 & 3.82 & $31.31 \mathrm{ab}$ & $16.34 \mathrm{ab}$ & $17.12 \mathrm{a}$ \\
200 & 3.39 & $34.85 \mathrm{a}$ & $17.45 \mathrm{a}$ & $18.23 \mathrm{a}$ \\
SE \pm & 0.200 & 2.082 & 1.092 & 1.891 \\
Variety & & & & \\
SAMNUT 23 & $4.36 \mathrm{a}$ & $31.43 \mathrm{ab}$ & $16.72 \mathrm{a}$ & $17.50 \mathrm{a}$ \\
SAMNUT 21 & $2.57 \mathrm{~b}$ & $26.11 \mathrm{~b}$ & $13.17 \mathrm{~b}$ & $13.95 \mathrm{~b}$ \\
SAMNUT 11 & $3.88 \mathrm{a}$ & $33.30 \mathrm{a}$ & $17.29 \mathrm{a}$ & $18.07 \mathrm{a}$ \\
SE \pm & 0.200 & 2.082 & 1.092 & 1.891 \\
Basin size & & & & \\
$3 \mathrm{~m} \times 3 \mathrm{~m}$ & $4.14 \mathrm{a}$ & $26.24 \mathrm{~b}$ & 13.99 & $14.79 \mathrm{a}$ \\
$3 \mathrm{~m} \times$ 4m & $3.42 \mathrm{~b}$ & $31.26 \mathrm{ab}$ & 16.17 & $16.95 \mathrm{ab}$ \\
$3 \mathrm{~m} \times 5 \mathrm{~m}$ & $3.25 \mathrm{~b}$ & $33.12 \mathrm{a}$ & 16.99 & $17.78 \mathrm{a}$ \\
SE \pm & 0.216 & 2.225 & 1.114 & 1.378 \\
Interaction & & & & \\
P x V & $*$ & NS & NS & NS \\
P x B & NS & NS & NS & $*$ \\
V x B & NS & NS & NS & NS \\
P x V x B & NS & NS & NS & NS \\
\hline percen & & & &
\end{tabular}

* Significant at 5 percent level. NS- Not significant. Means followed by the same letter within the same treatment group and year are statistically the same.

Table 4. Interaction between basin size and plant population and variety and plant population at 9WAS on TDM plant $^{-1}$ for the combined and 2003/2004 season

\begin{tabular}{llll}
\hline \multicolumn{4}{l}{$2003 / 2004$} \\
& \multicolumn{3}{l}{ Plant Population } \\
\hline & 50 & 100 & 200 \\
SAMNUT 23 & $4.24 \mathrm{~b}$ & $4.68 \mathrm{a}$ & $4.16 \mathrm{~b}$ \\
SAMNUT 21 & $1.87 \mathrm{f}$ & $2.55 \mathrm{e}$ & $3.27 \mathrm{c}$ \\
SAMNUT 11 & $4.70 \mathrm{a}$ & $3.27 \mathrm{c}$ & $2.73 \mathrm{~d}$ \\
SE \pm 0.375 & & & \\
$3 \mathrm{~m} \times 3 \mathrm{~m}$ & $10.70 \mathrm{~d}$ & $16.70 \mathrm{~b}$ & $16.96 \mathrm{~b}$ \\
$3 \mathrm{~m} \times 4 \mathrm{~m}$ & $13.56 \mathrm{c}$ & $18.99 \mathrm{ab}$ & $18.32 \mathrm{ab}$ \\
$3 \mathrm{~m} \times 5 \mathrm{~m}$ & $18.26 \mathrm{ab}$ & $15.67 \mathrm{c}$ & $19.42 \mathrm{a}$ \\
SE \pm 2.38 & & & \\
\hline
\end{tabular}

Means followed by the same letter(s) within the same row or columns are statistically similar at $\mathrm{P} \leq 0.05$. 
Table 5. Effect of plant population and basin size on total dry matter (g) at 12WAS of three groundnut varieties during 2003/2004, 2004/2005 and 2005/2006 dry season at Kadawa

\begin{tabular}{lllll}
\hline Treatments/Years & $2003 / 2004$ & $2004 / 2005$ & $2005 / 2006$ & Combined \\
\hline Plant Population ('000plants ha ${ }^{-1}$ ) & & & & \\
50 & 51.18 & 143.14 & 94.23 & 96.18 \\
100 & 55.92 & 141.65 & 95.86 & 97.81 \\
200 & 50.59 & 149.21 & 96.97 & 98.92 \\
SE \pm & 3.136 & 9.984 & 5.283 & 9.150 \\
Variety & & & & \\
SAMNUT 23 & $47.70 \mathrm{~b}$ & $121.13 \mathrm{~b}$ & $79.94 \mathrm{~b}$ & $82.92 \mathrm{c}$ \\
SAMNUT 21 & $54.33 \mathrm{~b}$ & $145.50 \mathrm{ab}$ & $95.44 \mathrm{a}$ & $98.42 \mathrm{~b}$ \\
SAMNUT 11 & $61.66 \mathrm{a}$ & $164.48 \mathrm{a}$ & $108.60 \mathrm{a}$ & $111.57 \mathrm{a}$ \\
SE \pm & 3.136 & 9.984 & 5.283 & 9.150 \\
Basin size & & & & \\
$3 \mathrm{~m} \times$ 3m & 52.11 & 144.43 & 93.84 & 96.79 \\
$3 \mathrm{~m}$ x 4m & 57.29 & 146.11 & 97.27 & 100.22 \\
$3 \mathrm{~m}$ x 5m & 54.29 & 140.86 & 92.59 & 95.90 \\
SE \pm & 2.339 & 8.501 & 4.642 & 5.327 \\
Interaction & & & & \\
P x V & NS & NS & NS & NS \\
P x B & $*$ & NS & NS & NS \\
V x B & NS & NS & NS & NS \\
P x V x B & NS & NS & NS & NS \\
\hline
\end{tabular}

* Significant at 5 percent level. NS- Not significant. Means followed by the same letter within the same treatment group and year are statistically the same.

Table 6. Interaction between basin size and plant population at 12WAS for TDM plant ${ }^{-1}$ for the 2003/2004 season

\begin{tabular}{llll}
\hline \multicolumn{4}{c}{ Basin Size } \\
& $3 \mathrm{~m} \times 3 \mathrm{~m}$ & $3 \mathrm{~m} \times 4 \mathrm{~m}$ & $3 \mathrm{~m} \times 5 \mathrm{~m}$ \\
\hline Plant Population ('000plants ha ${ }^{-1}$ ) & & & \\
50,000 & $11.47 \mathrm{f}$ & $18.73 \mathrm{~b}$ & $13.61 \mathrm{e}$ \\
100,000 & $19.15 \mathrm{~b}$ & $18.07 \mathrm{bc}$ & $14.65 \mathrm{e}$ \\
200,000 & $20.83 \mathrm{a}$ & $17.32 \mathrm{~cd}$ & $14.30 \mathrm{e}$ \\
SE \pm 1.718 & & & \\
\hline
\end{tabular}

Means followed by the same letter(s) within the same row or column are statistically similar at $\mathrm{P} \leq 0.05$.

A significant interaction was observed between plant population and basin size in 2003/2004 and this is shown in Table 6. The smallest basin at the highest plant population produced the highest TDM. For $3 \mathrm{~m} \times 3 \mathrm{~m}$ and $3 \mathrm{~m} \times$ $4 \mathrm{~m}$ basins the higher the plant population the more TDM realized. For the $3 \mathrm{~m} \times 5 \mathrm{~m}$ however, no significant difference was observed as plant population increased from 50,000 to 200,000 plants ha ${ }^{-1}$. At 50,000 plants ha ${ }^{-1}$ increasing the basin size to $3 \mathrm{~m} \mathrm{x} 4 \mathrm{~m}$ led to significantly more TDM; further increase to $3 \mathrm{~m} \times 5 \mathrm{~m}$ led to significantly low TDM. At 100,000 and 200,000 plants ha ${ }^{-1}$ increase in basin size to $3 \mathrm{~m} \mathrm{x} 5 \mathrm{~m}$ progressively led to reduction in total dry matter.

At harvest, plant population only in 2004/2005 significantly affected TDM when the 100,000 plants ha ${ }^{-1}$ resulted in more TDM than the 50,000 plants ha ${ }^{-1}$ and 200,000 plants ha ${ }^{-1}$ (Table 7). In other years and when combined, no significant differences were observed. In 2004/2005 significant differences among varieties in their TDM were observed. SAMNUT 21 and SAMNUT 11 had more TDM than SAMNUT 23 but SAMNUT 11 was at par with SAMNUT 23. In other years and the combined no significant differences were observed. 
Table 7. Effect of plant population and basin size on total dry matter $(\mathrm{g})$ at harvest of three groundnut varieties during 2003/2004, 2004/2005 and 2005/2006 dry season at Kadawa

\begin{tabular}{lllll}
\hline Treatments/Years & $2003 / 2004$ & $2004 / 2005$ & $2005 / 2006$ & Combined \\
\hline Plant Population ('000plants ha $\left.{ }^{-1}\right)$ & & & & \\
50 & 214.46 & $177.46 \mathrm{~b}$ & 296.64 & 229.52 \\
100 & 218.04 & $227.31 \mathrm{a}$ & 296.28 & 247.21 \\
200 & 196.73 & $174.55 \mathrm{~b}$ & 302.21 & 224.50 \\
SE \pm & 14.569 & 16.915 & 39.390 & 27.177 \\
Variety & & & & \\
SAMNUT 23 & 209.14 & $164.75 \mathrm{~b}$ & 294.70 & 222.86 \\
SAMNUT 21 & 212.91 & $220.45 \mathrm{a}$ & 297.62 & 243.73 \\
SAMNUT 11 & 207.18 & $194.12 \mathrm{ab}$ & 302.62 & 234.64 \\
SE \pm & 14.569 & 16.915 & 39.390 & 27.177 \\
Basin size & & & & \\
$3 m \times$ 3m & 220.44 & 181.92 & 291.43 & 231.27 \\
$3 \mathrm{~m}$ x 4m & 213.81 & 219.00 & 318.75 & 250.52 \\
$3 \mathrm{~m}$ x 5m & 194.97 & 178.39 & 284.95 & 219.44 \\
SE \pm & 10.421 & 14.722 & 20.193 & 18.505 \\
Interaction & & & & \\
P x V & NS & NS & NS & NS \\
P x B & NS & NS & NS & NS \\
V x B & NS & NS & NS & NS \\
P x V x B & NS & NS & NS & NS \\
\hline
\end{tabular}

*Significant at 5 percent level. NS- Not significant. Means followed by the same letter within the same treatment group and year are statistically the same.

Table 8. Effect of plant population and basin size on harvest index of three groundnut varieties in 2003/2004, 2004/2005 and 2005/2006 dry season at Kadawa

\begin{tabular}{lllll}
\hline Treatments/Years & $2003 / 2004$ & $2004 / 2005$ & $2005 / 2006$ & Combined \\
\hline $\begin{array}{l}\text { Plant population } \\
\left(\text { '000plants ha }{ }^{-1}\right)\end{array}$ & & & & \\
50 & $31.94 \mathrm{~b}$ & $18.57 \mathrm{~b}$ & 25.16 & $25.22 \mathrm{~b}$ \\
100 & $36.13 \mathrm{~b}$ & $14.37 \mathrm{c}$ & 24.80 & $25.10 \mathrm{~b}$ \\
200 & $39.70 \mathrm{a}$ & $22.02 \mathrm{a}$ & 27.10 & $29.78 \mathrm{a}$ \\
SE \pm & 2.618 & 1.546 & 2.443 & 2.469 \\
Variety & & & & \\
SAMNUT 23 & $48.30 \mathrm{a}$ & $25.55 \mathrm{a}$ & $31.69 \mathrm{a}$ & $35.18 \mathrm{a}$ \\
SAMNUT 21 & $26.59 \mathrm{~b}$ & $13.12 \mathrm{c}$ & $19.90 \mathrm{c}$ & $19.87 \mathrm{c}$ \\
SAMNUT 11 & $32.88 \mathrm{~b}$ & $16.29 \mathrm{~b}$ & $25.98 \mathrm{~b}$ & $25.05 \mathrm{~b}$ \\
SE \pm & 2.618 & 1.546 & 2.443 & 2.469 \\
Basin size & & & & \\
$3 \mathrm{~m} \times$ 3m & 38.61 & 18.87 & 24.06 & 27.18 \\
$3 \mathrm{~m} \times$ 4m & 35.69 & 18.47 & 27.43 & 27.19 \\
$3 \mathrm{~m} \times$ 5m & 33.48 & 17.61 & 26.08 & 25.72 \\
SE \pm & 2.455 & 0.994 & 1.593 & 1.922 \\
Interaction & & & & \\
P x V & NS & NS & NS & NS \\
P x B & NS & NS & NS & NS \\
V x B & NS & NS & NS & NS \\
P x V x B & NS & NS & NS & NS \\
\hline
\end{tabular}

NS- Not significant. Means followed by the same letter within the same treatment group and year are statistically the same. 
The effect of plant population on harvest index (HI) was significant in 2003/2004 and 2004/2005 (Table 8). In $2005 / 2006$, no significant effect was observed. The combined result revealed that HI was significantly highest when groundnut was planted at 200,000 plants ha ${ }^{-1}$. HI of the varieties was significantly different. SAMNUT 23 exhibited the highest HI compared to SAMNUT 21 and SAMNUT 11 across the years and when over three years averaged. Basin size had no significant effect on $\mathrm{HI}$ in all the years and the combined.

\section{Discussion}

The results reveal that plant population and basin size have variable effects on dry matter production and yield of groundnut. These effects differed according to variety and growing season. Initially increase in plant population from 50,000 to 200 , 000 plants $^{-1} a^{-1}$ led to increase in TDM, however this was evident only during vegetative growth stages and early reproductive stages. When the crop attained full canopy closure the difference in TDM was slight. This means that increasing the plant population led to increase in TDM until an optimum was reached beyond which further increases in number of plants did not produce significant changes in TDM. The results show that more dry matter was produced at the higher plant population. This is attributed to the fact that due to higher competition between plants individual dry matter decreased significantly compared to high total mass from a community of plants because of the higher number of plants per unit area. In experiments with Napier grass, Wijitphan et al. (2009) reported a significant effect of plant spacing on dry matter production at 50x40.

Similar results were reported by Tanimu et al. (1998) with different plant spacing. This result is similar to the work of Nedelcu et al. (1986) who observed maximum dry matter accumulation of $62 \mathrm{~g} / \mathrm{plant}$ at 100,000 plants ha ${ }^{-1}$. On the hand Bell et al. (1987) observed an increase in biological yield with increasing plant population from 88,000 to 394,000 plants ha ${ }^{-1}$. Crops sown at high density are able to attain faster canopy cover than those at low density by especially by harnessing solar radiation, nutrients and moisture. The increased dry matter accumulation is related to the lesser time required for plants in high density plant spacing's to achieve a higher solar radiation interception than plants in the lower plant population. Thus total dry matter increases until a point is reached where increases in plant numbers has no positive impact on the total dry matter achievable.The low dry matter recorded at 200,000 plants ha $\mathrm{h}^{-1}$ is also an indication of competition for available moisture. Although in this study water was not a limiting due to availability of irrigation water, the higher numbers of plants $\left(200000\right.$ plants ha $\left.^{-1}\right)$ per unit area could have led to a higher than normal moisture demand than was obtained in plots having 100000 plants $\mathrm{ha}^{-1}$ or 50000 plants ha ${ }^{-1}$. Moisture stress is known to have adverse effects on yield. Drought stress at $50 \%$ flowering in chick peas was found to have a more damaging effect on dry matter production than drought stress at $50 \%$ podding phase (Patel \& Hemantaranjan, 2012). (Tatar \& Gevrek, 2008) observed a decline in dry matter produced by wheat after onset of stress treatment. Research by Travlos and Karamanos (2008) revealed the beneficial effect of adequate water supply on growth and dry matter production of marama.

Looking at the dry matter produced per plant across the three growing seasons, slightly warmer temperatures during 2005 and 2006 resulted to more vigorous plant growth. The differences in dry matter produced during the years of experimentation are attributed to seasonal variations in temperature (data not shown). Anonymous (2002) reported that cultivation of groundnut is limited by the occurrence of frost. On the other hand extremely high temperatures are detrimental to growth and development of the crop (Ishag, 2000). Consequently total dry matter was generally lower in 2003/2004 than in 2004/2005 and 2005/2006. The slower growth rate due to the cooler conditions during early stages caused slower biomass production and accumulation in successive stages indicating the importance of initial crop growth for final yield.

Vara Prasad et al. (2000) also found that exposure to high air and or soil temperatures significantly reduced dry matter production, partitioning of dry matter to pods and pod yields. Irrespective of season the results reveal an increasing trend in dry matter over the sampling period.

A differential response of the varieties was attributed to variation in their genetic makeup. Throughout the early growth stages ( 3 and 6 WAS) differences in dry matter production among the varieties were slight. This pattern was similar for the three years. However at 9 and 12 WAS SAMNUT 11 displayed superiority in terms of dry matter production. The trend was reversed by harvest time when SAMNUT 21 exhibits the highest dry matter production. Although SAMNUT 21 and SAMNUT 11 produced significantly higher amount of dry matter than SAMNUT 23, which is expected, SAMNUT 21 produced the highest total dry matter plant ${ }^{-1}$, while SAMNUT 11 produced highest total dry matter hectare ${ }^{-1}$. The high dry matter yield observed in SAMNUT 11 is attributed to its more profuse branching habit. This was due to its superiority in growth attributes such as number of branches per plant and number of leaves per plant (data not shown). As a late maturing crop, which completes its life cycle in 130-150, more time was allocated to partitioning of assimilates to vegetative parts, which include leaves, stem and branches in addition to other reproductive parts. There is an indication that there are differences in partitioning of 
dry matter to pod by the different varieties in response to environmental factors such as temperature. However dry matter accumulation in each part of the plants continued until maturity although production rate differed depending on variety and age.

Harvest index; the ratio of biomass yield to pod yield is an important indicator of yield in groundnut. There was very little variation in the harvest index indicating high stability of this character in the groundnut crop. SAMNUT 23 exhibited highest harvest index under irrigated conditions. Muldoon (1985) reported that differences between cultivars were related to differences in harvest index and in the rate of pod filling.

In conclusion, the study has revealed that dry matter production for a community of crops increases with increase in plant population until a point is reached where increases in population do not lead to corresponding significant increases in production of dry matter. For our study, highest dry matter production was observed at 100.000 plants $\mathrm{ha}^{-1}$, while harvest index was significantly highest at 200,000 plants $\mathrm{ha}^{-1}$. Of the varieties used, SAMNUT 23 exhibited highest harvest index.

\section{References}

Ahmad, R., Hassan, B., \& Jabran, K. (2007). Improving crop harvest index. Retrieved from http://DAWN.com

Anonymous (2002). The Tropical Agriculturist. London and Oxford: Macmillan Education Ltd.

Bell, M. J., Muchow, R. C., \& Wilson, G. L. (1987). The effect of plant population on peanuts (Arachis hypogaea) in amonsoonal tropical environment. Field Crops Res., 17, 91-107. http://dx.doi.org/10.1016/0378-4290(87)90085-2

Bell, M. J., Wright, G. C., \& Hammer, G. L. (1992). Night temperature affects radiation use in peanut. Crop Science, 32, 1329-1335. http://dx.doi.org/10.2135/cropsci1992.0011183X003200060005x

Bindi, M., Sinclair, T. R., \& Harrison, J. (1999). Analysis of seed growth by linear increase in harvest index. Crop Sci., 39, 486-493. http://dx.doi.org/10.2135/cropsci1999.0011183X0039000200031x

De Waele, D., \& Swanevelder, C. J. (2001). Groundnut. In R. H. Raemaekers (Ed.), Crop Production in Tropical Africa (pp. 747-763). DGIC, Brussels, Belgium.

Duncan, D. B. (1955). Multiple Range and Multiple F- test. Biometrics, II, 1-42. http://dx.doi.org/10.2307/3001478

Ishag, H. M. (2000). Phenotypic and yield responses of Irrigated groundnut cultivars in a hot environment. Exp. Agric., 36, 303-312. http://dx.doi.org/10.1017/S0014479700003021

Travlos, I. S., \& Karamanos, A. J. (2008). Growth Responses of Maramabean (Tylosema esculentum) to Water Deficit Conditions. International Journal of Agricultural Research, 3, 155-160. http://dx.doi.org/10.3923/ijar.2008.155.160

Muldoon, D. K. (1985). The effect of time of sowing and row sowing on the maturity and yield of three groundnut cultivars under irrigation. Australian Journal of Agricultural Research, 36(4), 615-621. http://dx.doi.org/10.1071/AR9850615

Nedelcu, P., Pop, L., \& Pitis, S. (1986). Studies on the physiology of new cultivars and lines of groundnuts grown on irrigated sandy soils. Buletinul informative al Academisi de Stinte, Agricole si Silvice, 16, 77-89.

Tatar, O., \& Gevrek, M. N. (2008). Influence of Water Stress on Proline Accumulation, Lipid Peroxidation and Water Content of Wheat. Asian Journal of Plant Sciences, 7, 409-412. http://dx.doi.org/10.3923/ajps.2008.409.412

Patel, P. K., \& Hemantaranjan, A. (2012). Salicylic acid induced Alteration in Dry matter Partitioning, Antioxidant Defense System and Yield in Chickpea (Cicer arietinum L.) under Drought Stress. Asian Journal of Crop Science, 4, 86 -102. http://dx.doi.org/10.3923/ajcs.2012.86.102

Wijitphan, S., Lorwilai, P., \& Arkaseang, C. (2009). Effects of plant spacing on yields and nutritive values of Napier grass (Penisetum purpureum). Under intensive management of Nitrogen fertilizer and irrigation. Pakistan Journal of Nutrition, 8, 1240-1243. http://dx.doi.org/10.3923/pjn.2009.1240.1243

Tanimu, B., Abdullahi, B., Olorunju, P. E., \& Ibrahim, R. (1998). Effect of inter and intra row spacings on growth and yield of groundnut in the Northern Guinea Savanna of Nigeria. The Plant Scientist, 1(1), 69-82.

Vara Prasad, P. V., Craufurd, P. Q., \& Summerfield, R. J. (2000). Effect of high soil temperature on dry matter production, pod yield and yield components of groundnut. Plant and soi, 222(1-2), 231-239. http://dx.doi.org/10.1023/A:1004793220787 


\section{Copyrights}

Copyright for this article is retained by the author(s), with first publication rights granted to the journal.

This is an open-access article distributed under the terms and conditions of the Creative Commons Attribution license (http://creativecommons.org/licenses/by/3.0/). 